\title{
wwwceasopisismapanpl PAN 级定 \\ Methods of the Detection and Identification of Structural Defects in Saturated Metallic Composite Castings
}

\author{
K. Gawdzińska \\ Faculty of Marine Engineering, Maritime University of Szczecin, Willowa 2-4, 71-650 Szczecin, Poland \\ Corresponding author. E-mail address: k.gawdzinska@am.szczecin.pl
}

Received 01.06.2017; accepted in revised form 18.07.2017

\begin{abstract}
Diagnostics of composite castings, due to their complex structure, requires that their characteristics are tested by an appropriate description method. Any deviation from the specific characteristic will be regarded as a material defect. The detection of defects in composite castings sometimes is not sufficient and the defects have to be identified. This study classifies defects found in the structures of saturated metallic composite castings and indicates those stages of the process where such defects are likely to be formed. Not only does the author determine the causes of structural defects, describe methods of their detection and identification, but also proposes a schematic procedure to be followed during detection and identification of structural defects of castings made from saturated reinforcement metallic composites. Alloys examination was conducted after technological process, while using destructive (macroscopic tests, light and scanning electron microscopy) and non-destructive (ultrasonic and X-ray defectoscopy, tomography, gravimetric method) methods. Research presented in this article are part of author's work on castings quality.
\end{abstract}

Keywords: Casting, composite, Structural defects, Detection and identification

\section{Introduction}

Diagnostics is [1] an area of science that deals with the recognition of the examined condition of objects by classifying it to a given type, kind, group, and by explaining the causes of the condition, determination of the present condition and projected development. Diagnostics is postulated to be true and relevant, i.e. it should take into account specific characteristics of the condition and/or change (cause), and to give a possibly full recognition of the type of determinant (e.g. defect) and the development of the examined effect. We can therefore assume that while analyzing the quality of a casting after the technological process or during its operational use, its diagnostics is necessary, and so is the determination of the method of detecting and identifying possible product defects. This work describes the causes of composite defects (classified and referred to as structural defects according to [2]) and specifies methods of defect detection and identification. Structural defects in castings of saturated reinforcement metallic composites (made in accordance with the technology [3] shown in Table 1) are analysed from the viewpoint of their possible detection and identification. Some of the defects, and methods of their detection and identification, have been extensively studied and described in the literature $[4,5,6]$. Other defects have not been investigated or the scope and the results of the tests were not sufficient to provide information necessary for the assessment of method applicability. The considerations that follow are aimed at finding answers to the question: which of the 
methods testing specific defects may or may not be used without experimental tests that define their usefulness? This problem should be considered using a subtle division between defect detection (i.e. establishing the fact of occurrence) and identification (description, recognition of irregularities based on some characteristics).

Table 1

Classification of structural defects in metal composites castings and their causes [2]

\begin{tabular}{|c|c|c|c|}
\hline $\begin{array}{c}\text { No Subgroup } \\
\text {. } \text { of defects }\end{array}$ & Defect & $\begin{array}{l}\text { Manufacturing stage } \\
\text { of possible defect } \\
\text { formation }\end{array}$ & Causes of defect formation \\
\hline
\end{tabular}

\begin{tabular}{|c|c|c|c|c|}
\hline \multirow{7}{*}{1.} & \multirow{7}{*}{ 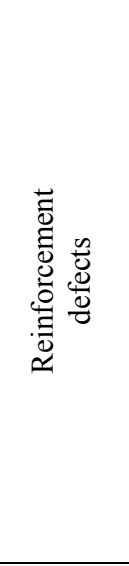 } & $\begin{array}{l}\text { 1.1. Inhomogeneity of shape } \\
\text { and dimensions of the } \\
\text { reinforcement elements }\end{array}$ & $\begin{array}{l}\text { Delivery of material } \\
\text { reinforcement }\end{array}$ & Bad quality of reinforcement (at manufacturer's) \\
\hline & & $\begin{array}{l}\text { 1.2. Inhomogeneity of } \\
\text { reinforcement distribution }\end{array}$ & $\begin{array}{l}\text { Delivery of material } \\
\text { reinforcement }\end{array}$ & $\begin{array}{l}\text { Mechanical damage, bad quality of reinforcement } \\
\text { (at manufacturer's) e.g. varying quantity of fibres }\end{array}$ \\
\hline & & $\begin{array}{l}\text { 1.3. Foreign matter } \\
\text { in the reinforcement }\end{array}$ & $\begin{array}{l}\text { Delivery of material } \\
\text { reinforcement }\end{array}$ & Bad quality of reinforcement (at manufacturer's) \\
\hline & & \multirow{3}{*}{$\begin{array}{l}\text { 1.4. Deformation of the } \\
\text { reinforcement structure }\end{array}$} & $\begin{array}{l}\text { Preparation of } \\
\text { reinforcement }\end{array}$ & Mechanical damage \\
\hline & & & $\begin{array}{l}\text { Preparation of } \\
\text { a mould }\end{array}$ & Mechanical damage \\
\hline & & & Infiltration & Excessive pressure or matrix metal flow rate \\
\hline & & $\begin{array}{l}\text { 1.5. Improper positioning of the } \\
\text { reinforcement structure }\end{array}$ & $\begin{array}{l}\text { Preparation of the } \\
\text { mould }\end{array}$ & Displacement of reinforcement structure in the mould \\
\hline \multirow{3}{*}{2.} & \multirow{3}{*}{ 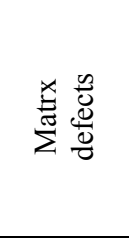 } & \multirow{3}{*}{ 2.1. Improper matrix structure } & $\begin{array}{l}\text { Delivery of matrix } \\
\text { material }\end{array}$ & Improper chemical composition \\
\hline & & & $\begin{array}{l}\text { Preparation of liquid } \\
\text { metal }\end{array}$ & $\begin{array}{l}\text { Too high or too low temperature of matrix metal, inadequate } \\
\text { chemical composition of the matrix metal, improper } \\
\text { modification or lack thereof }\end{array}$ \\
\hline & & & Solidification & Improper temperature of the mould \\
\hline \multirow{3}{*}{3.} & \multirow{3}{*}{ 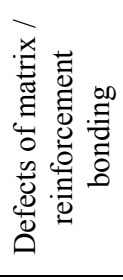 } & $\begin{array}{l}\text { 3.1. No transitional zone or its } \\
\text { discontinuity at the matrix/ } \\
\text { reinforcement }{ }^{*} \text { interface }\end{array}$ & $\begin{array}{l}\text { Preparation of } \\
\text { reinforcement }\end{array}$ & $\begin{array}{l}\text { Improper preparation of the fibres, contaminated reinforcement } \\
\text { material, failure to degrease the reinforcement }\end{array}$ \\
\hline & & \multirow{2}{*}{$\begin{array}{l}\text { 3.2. Brittle phases at the - } \\
\text { reinforcement } / \text { matrix } \\
\text { interface }\end{array}$} & $\begin{array}{l}\text { Preparation of } \\
\text { reinforcement }\end{array}$ & $\begin{array}{l}\text { Improper preparation of the fibres, e.g. lack of coating, } \\
\text { contaminated reinforcement }\end{array}$ \\
\hline & & & Infiltration & $\begin{array}{l}\text { Incorrect interaction between the reinforcement and matrix } \\
\text { material }\end{array}$ \\
\hline \multirow{8}{*}{4.} & \multirow{8}{*}{ 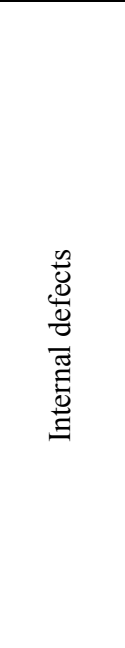 } & \multirow{3}{*}{ 4.1. Inclusions } & $\begin{array}{l}\text { Delivery of matrix } \\
\text { material }\end{array}$ & Contaminated metallic charge, improper chemical composition \\
\hline & & & $\begin{array}{l}\text { Preparation of liquid } \\
\text { metal }\end{array}$ & Improper melting and refining process \\
\hline & & & Infiltration & $\begin{array}{l}\text { Erosion of the mould or its coating due to wrong material used, } \\
\text { or too high rate of metal matrix flow }\end{array}$ \\
\hline & & $\begin{array}{l}\text { 4.2. Voids in the space of the } \\
\text { reinforcement }\end{array}$ & Infiltration & $\begin{array}{l}\text { Too low pressure of infiltration, too low temperature of the } \\
\text { reinforcement, metal matrix or mould }\end{array}$ \\
\hline & & 4.3. Occluded blow holes & Infiltration & $\begin{array}{l}\text { Improper feeding of matrix metal, too fast infiltration, too low } \\
\text { temperature of the reinforcement, metal matrix or mould }\end{array}$ \\
\hline & & \multirow{2}{*}{ 4.4. Precipitated blow holes } & $\begin{array}{l}\text { Delivery of matrix } \\
\text { material }\end{array}$ & Contaminated metallic charge \\
\hline & & & $\begin{array}{l}\text { Preparation of liquid } \\
\text { metal }\end{array}$ & $\begin{array}{l}\text { Improperly prepared material of the matrix, inappropriate } \\
\text { melting or refining }\end{array}$ \\
\hline & & 4.5. Gas porosity & $\begin{array}{l}\text { Delivery of matrix } \\
\text { material }\end{array}$ & Contaminated metal charge \\
\hline
\end{tabular}


Table 1 (cont.)

\begin{tabular}{|c|c|c|c|c|}
\hline No & $\begin{array}{l}\text { Subgroup } \\
\text { of defects }\end{array}$ & Defect & $\begin{array}{l}\text { Manufacturing stage } \\
\text { of possible defect } \\
\text { formation }\end{array}$ & Causes of defect formation \\
\hline & & Gas porosity & $\begin{array}{l}\text { Preparation of liquid } \\
\text { metal }\end{array}$ & $\begin{array}{l}\text { Improperly prepared material of the matrix, inappropriate } \\
\text { melting or refining }\end{array}$ \\
\hline & & Shrinkage cavity & Solidification & $\begin{array}{l}\text { Improper feeding of the mould due to bad design of casting or } \\
\text { mould or improper thermal conditions }\end{array}$ \\
\hline & & Shrinkage porosity & Solidification & $\begin{array}{l}\text { Improper feeding of the mould due to bad design of casting or } \\
\text { mould or improper thermal conditions }\end{array}$ \\
\hline \multirow{7}{*}{5.} & \multirow{7}{*}{ 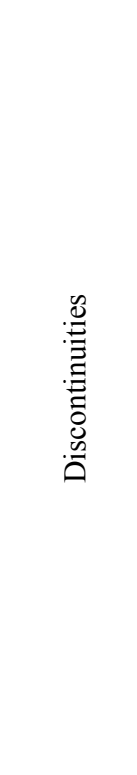 } & \multirow[b]{2}{*}{$\begin{array}{l}\text { 5.1. Cracks in reinforcement } \\
\text { elements }\end{array}$} & Infiltration & Excessive infiltration pressure or matrix metal flow rate \\
\hline & & & Cooling down & $\begin{array}{l}\text { Internal stresses in the casting volume due to casting or mould } \\
\text { design, improper temperature of the mould, too intense cooling } \\
\text { of the mould, too late removal of the casting from the mould }\end{array}$ \\
\hline & & 5.2. Cracking of the matrix & Cooling down & $\begin{array}{l}\text { Internal stresses in the casting volume due to casting or mould } \\
\text { design, improper temperature of the mould, too intense cooling } \\
\text { of the mould, too late removal of the casting from the mould }\end{array}$ \\
\hline & & $\begin{array}{l}\text { 5.3. Cracks at the matrix/ } \\
\text { reinforcement interface }\end{array}$ & Cooling down & $\begin{array}{l}\text { Improperly selected materials of the matrix and reinforcement, } \\
\text { internal stresses in the casting volume due to wrong casting or } \\
\text { mould design, improper temperature of the mould, too intense } \\
\text { cooling of the mould, casting removed too late from the mould }\end{array}$ \\
\hline & & $\begin{array}{l}\text { 5.4. Hot cracking } \\
\text { of the casting }\end{array}$ & Cooling down & $\begin{array}{l}\text { Internal stresses in the casting volume due to casting or mould } \\
\text { design, improper temperature of the mould, too intense cooling } \\
\text { of the mould, too late removal of the casting from the mould }\end{array}$ \\
\hline & & \multirow{2}{*}{$\begin{array}{l}\text { 5.5. Cold cracking } \\
\text { of the casting }\end{array}$} & Cooling down & $\begin{array}{l}\text { Internal stresses in the casting space due to improper casting or } \\
\text { mould design, improper mould temperature, too intense cooling } \\
\text { of the mould }\end{array}$ \\
\hline & & & $\begin{array}{l}\text { Removal of the } \\
\text { casting from the } \\
\text { mould }\end{array}$ & Casting damage during knocking out or straightening \\
\hline
\end{tabular}

* If required.

\section{Methods for the detection of defects in reinforcement and matrix, matrix/ reinforcement bonding, internal defects and discontinuities}

The analysis of casting quality in this work has been carried out using non-destructive methods (ultrasonic and X-ray defectoscopy, tomography, gravimetric method) and destructive (macroscopic tests, light and scanning electron microscopy). These were complemented with computer image analysis, and statistical and stereological methods (described in detail in $[2,7]$ ). The quality of castings was tested after the manufacturing process.

\section{- The detection and testing of reinforcement defects}

Three of the defect types belonging to this group, namely: inhomogeneity of the shape and dimensions of the reinforcing material, inhomogeneity of reinforcing elements distribution, foreign matter in the reinforcement, may be detected by microscopic or tomographic examination, but their quantitative assessment (i.e. detailed description identification) requires the use of computer image analysis methods and mathematical description. Tests of these defects, therefore, include two stages:

1) producing a reinforcement image,

2) description of the reinforcement image.

The value of both types of microscopic examination is presented in Figure 1. X-ray microanalysis offers additional assistance in phase identification, that of foreign matter in particular. Image analysis can also serve for quantitative description of the defects detected by any method. Image analysis is used in the same way for any of the defects.

Two other types of defects of the same subgroup (Table 1): deformation of the reinforcement structure, improper positioning of the reinforcement structure, are of the macroscopic nature. These defects can be revealed by macroscopic observation and non-destructive methods such as Xray or ultrasound defectoscopy. The effectiveness of macroscopic observation is presented in Figure 2.

\section{- The detection and testing of matrix defects}



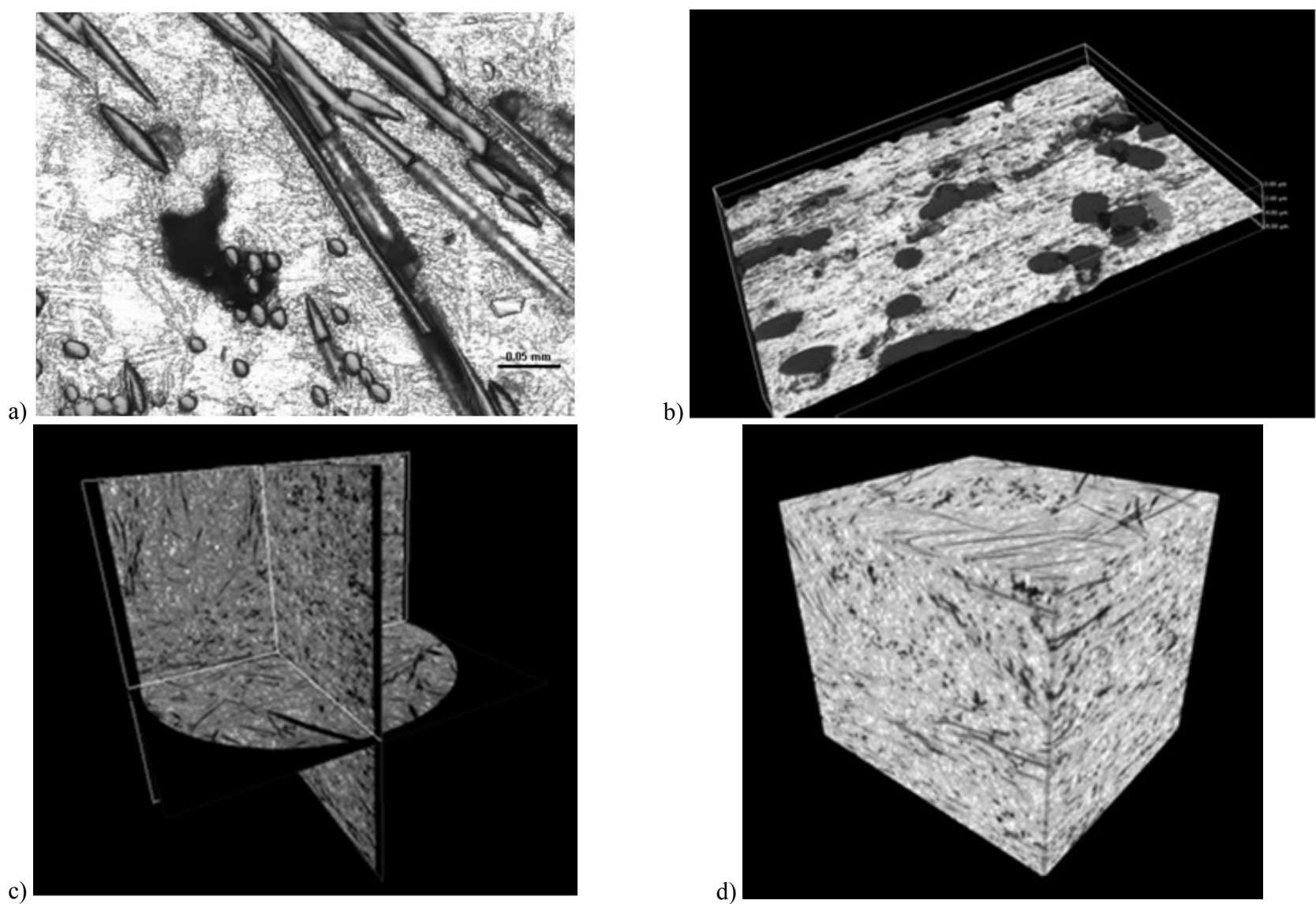

b)

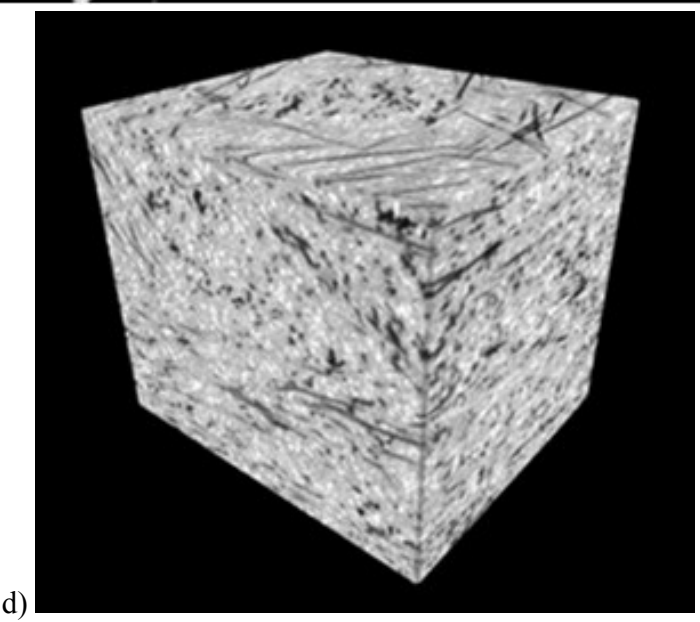

Fig. 1. Examples of microscopic $(a, b)$ and tomographic examination $(c, d)$ for the detection of: inhomogeneous distribution of reinforcement elements, composite (AlSi11/C)

a)

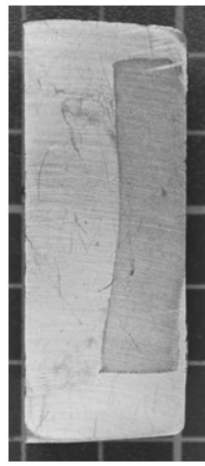

Fig. 2. Examples b)

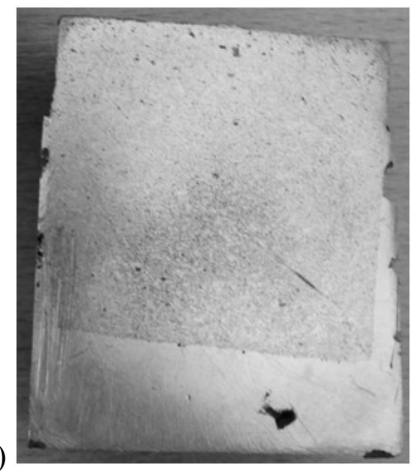

the composite: a) reinforcement deformation; reinforcement: aluminosilicate fibres, matrix: AlSi11 (macroscopic tests); b) improper positioning of the reinforcement structure; reinforcement: aluminosilicates, matrix: Wood alloy; clearly visible displacement of the reinforcement preform in the casting space (macroscopic tests).

Matrix defects are detectable and identifiable by light and scanning electron microscope examination. For the determination of the matrix structure constituents it is sometimes recommended to use X-ray microanalysis in questionable cases. In order to get quantitative description of matrix structure (identification) it may be necessary to apply computer image analysis. The applicability and value of these methods in matrix tests are obvious $[8,9,10$, 11].

\section{- The detection and testing of defects in matrix/ reinforcement bonding}

Defects of this subgroup can be examined by light or scanning electron microscopy. These methods are used to determine:

- presence or absence of a transitional layer at the matrix/ reinforcement interface (detection),

- type of this layer and its structure (identification).

Full identification of these layers, e.g. the chemical composition of the phases $[10,11,12]$, should be performed using $\mathrm{X}$-ray microanalysis, as shown in Figure 3.

\section{- Detection and testing of internal defects}

Defects in this subgroup include inclusions and various forms of porosity.

Inclusions are principally tested by standard microscopic methods $[8,9,10]$. Due to the presence of reinforcement in the composite, macroscopic tests and defectoscopic X-ray and 
ultrasonic tests may have limited application and only in relation to large inclusions.

Porosity tests, as shown in Table 1, do and can include: determination of the total casting porosity; porosity type identification based on:

- $\quad$ shape of pores,

- pore size,

- location in the casting space and relative to reinforcement elements.

a
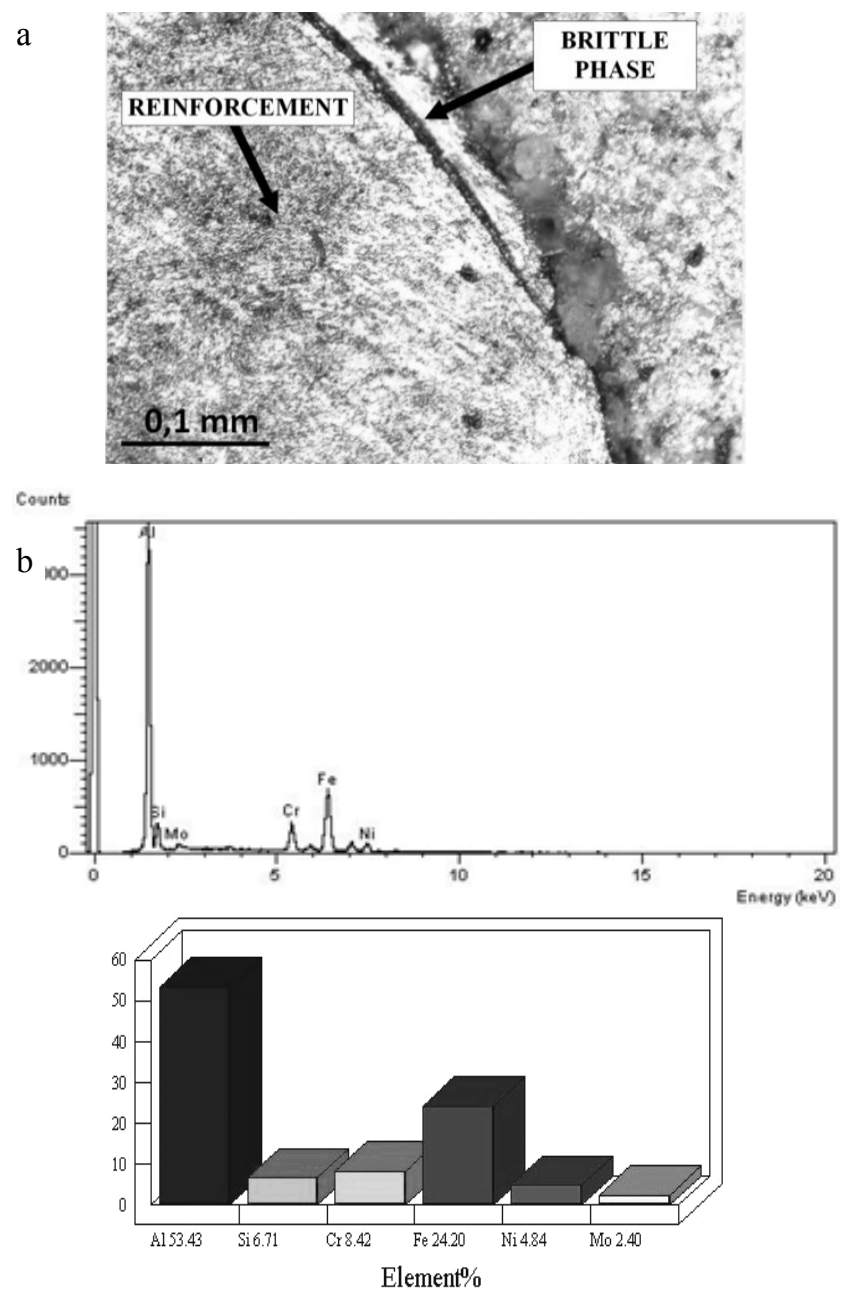

Fig. 3. The presence of brittle phases; a) reinforcement, stainless steel, matrix: aluminium (light microscopy); b) chemical composition of the brittle phase (X-ray microanalysis)

Porosity tests can be carried out by non-destructive methods: gravimetry; ultrasonic and X-ray (Figure 4); tomography,

and destructive methods including:

- macroscopic tests,

- microscopic examination using light or scanning electron microscope.

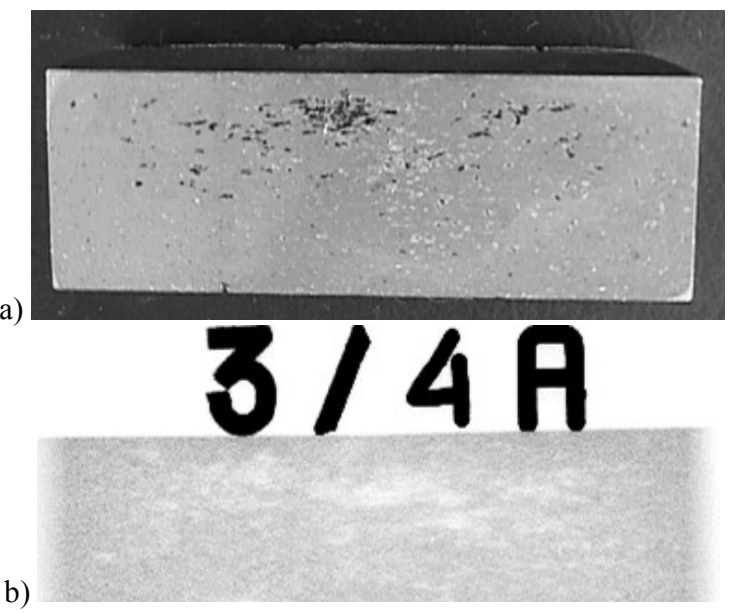

Fig. 4. Shrinkage porosity - reinforcement: aluminosilicate fibres, matrix: AlSi11; a) composite structure (macroscopic tests), b) the

same composite - a digital image from a radiogram (X-ray defectoscopy)

The quantitative estimation of porosity: size, shape and distribution of the pores may be done by image analysis. For a full assessment of porosity character in most cases several test methods must be used.

\section{- Detection and testing of discontinuities}

The defects of this subgroup include cracks:

in the matrix structure;

in reinforcement elements;

at the reinforcement - matrix interface,

which can be detected only by microscopic tests, and so-called hot and cold cracks of macroscopic nature. The detection of macroscopic cracks can be facilitated by deep etching and penetrating tests, defectoscopic ultrasonic or X-ray tests. The method of detection of these defects does not differ from that used in locating similar defects in more conventional materials.

\section{Summary and conclusions}

Diagnostics of composite castings, due to their complex structure, requires that their characteristics are tested by an appropriate description method. Any deviation from the specific characteristic will be regarded as a material defect. The detection of defects in composite castings sometimes is not sufficient and the defects have to be identified (i.e. explicitly acknowledged type of defect, e.g. porosity). In some cases various test methods should be combined for the defect identification. This work integrates information on the quality of the composites under consideration, the result of many years of author' research.

In macroscopic examination of composite specimens, observations of flat surfaces and fractures are made. Due to the flat surface, it is possible to identify precipitates that do not belong to the structure of matrix or reinforcement, pores or discontinuities of large dimensions. It is very difficult, but possible, to make observations of fractures in metal composite 
castings, although much experience is required. Metallographic examination with a light microscope allows us to distinguish structural components and their quantities, distribution, size, shape, and sometimes their identification is possible. Due to the specific structure of saturated composites, the scope of light microscope examination is much wider than in the case of matrix, reinforcement and the bonding of these two components. This specification also includes porosity, especially the one created due to insufficient infiltration of reinforcement by liquid matrix. These characteristic elements of composite structure, however, may be too small for examination, even when magnified. It may also be difficult to identify the components of the composite.

Table 2

Methods for the detection and identification of structural defects in saturated metal composite castings [on the basis of 2, 7-8,11]

\begin{tabular}{|c|c|}
\hline $\begin{array}{c}\text { Defect } \\
\text { subgroup }\end{array}$ & Defect \\
\hline \multirow{4}{*}{ 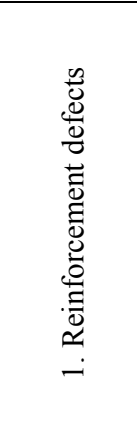 } & $\begin{array}{l}\text { 1.1. Inhomogeneity of shape and dimensions } \\
\text { of the reinforcement elements } \\
\text { 1.2. Inhomogeneity of reinforcement elemen } \\
\text { distribution }\end{array}$ \\
\hline & 1.3. Foreign matter in the reinforcement \\
\hline & $\begin{array}{l}\text { 1.4. Deformation of the reinforcement } \\
\text { structure }\end{array}$ \\
\hline & $\begin{array}{l}\text { 1.5. Improper positioning of the reinforceme } \\
\text { structure }\end{array}$ \\
\hline 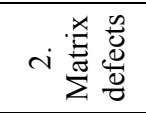 & 2.1. Improper matrix structure \\
\hline 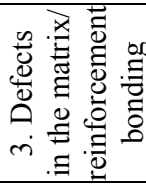 & $\begin{array}{l}\text { 3.1. No transition zone or its discontinuity at } \\
\text { the matrix/reinforcement interface } \\
\text { 3.2. Brittle phases created at the matrix/ } \\
\text { reinforcement interface }\end{array}$ \\
\hline & 4.1. Inclusions \\
\hline 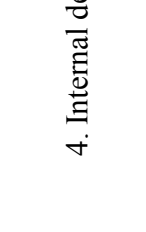 & $\begin{array}{l}\text { 4.2. Voids in the space of the reinforcement } \\
\text { 4.3. Occluded blow holes } \\
\text { 4.4. Precipitated blow holes } \\
\text { 4.5. Gas porosity } \\
\text { 4.6. Shrinkage cavity } \\
\text { 4.7. Shrinkage porosity }\end{array}$ \\
\hline
\end{tabular}

Methods of detection and identification of defects, whose applicability:

\begin{tabular}{cc}
\hline does not require experimental verification & $\begin{array}{c}\text { requires experimental } \\
\text { (detection) }\end{array}$ \\
verification (identification)
\end{tabular}

- Microscopic tests

- light,

- scanning electron

- Microscopic tests

- light,

- scanning electron

- Macroscopic tests

- Macroscopic tests*

- X-ray defectoscopy*

- Ultrasonic defectoscopy ${ }^{*}$

- Microscopic tests

- light,

- scanning electron

- Microscopic tests

- light,

- scanning electron
- Computer image analysis

- Tomography

- X-ray microanalysis

- Microscopic tests

- light,

- scanning electron

- Ultrasonic and X-ray defectoscopy ${ }^{*}$

- Macroscopic tests

- Gravimetric tests

- Microscopic tests

- light,

- scanning electron

- Computer image analysis.

- Ultrasonic and X-ray defectoscopy

- Tomography

5.1. Cracks in reinforcement elements

5.2. Cracking of the matrix

5.3. Cracks in the reinforcement/matrix interface

- Microscopic tests

- light,

- scanning electron

- Macroscopic tests

- Microscopic tests

5.4. Hot cracks of the casting

5.5. Cold cracks of the casting

- light,

- scanning electron

- Ultrasonic and X-ray defectoscopy

- Penetrating tests

${ }^{*}$ Only for large defects. ${ }^{* *}$ If required. 


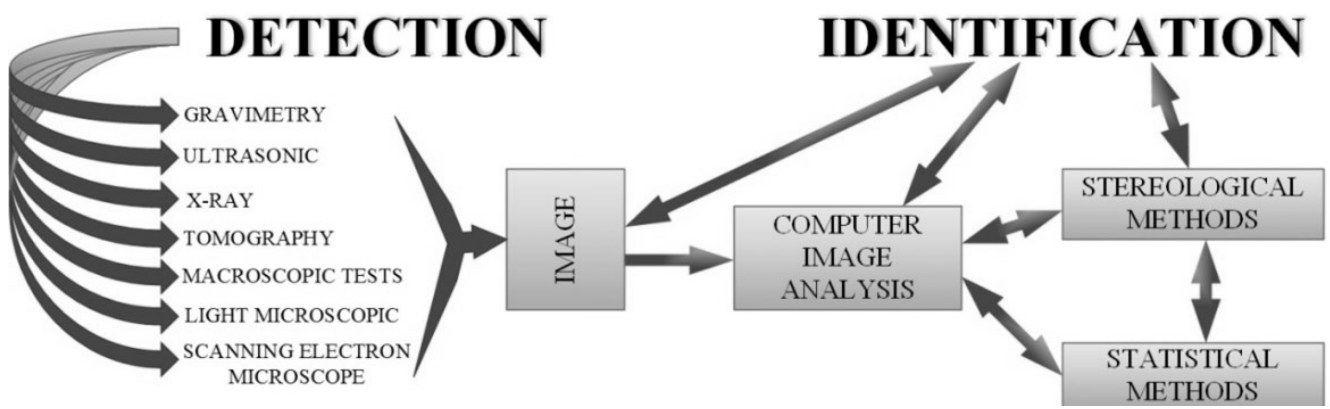

Fig. 5. A schematic procedure for the detection and identification of structural defects in castings of metal composites

Light microscope tests can also be a basis for further investigation using computer image analysis. Tests using scanning electron microscope, which can magnify an image, may supplement and confirm the tests carried out on a light microscope or tomograph. Specimens for this test can be prepared in the form of microsections or fractures. These tests enable observation of very small precipitates of different phases, even structural defects, such as dislocations, inappropriate bonding of composite components etc. They can make up a basis for other tests, e.g. tomography or X-ray microanalysis, the latter enabling direct determination of chemical composition of the observed structural elements.

Ultrasonic defectoscopy tests of the examined materials may relate to the impact of composite density on the speed of ultrasonic wave propagation and attenuation coefficient in saturated metal composite castings. We use these tests for the detection of discontinuities (porosities) or precipitates. The identification and verification of this type of defects require other methods to be employed, e.g. light microscopy. The same is true for X-ray defectoscopy, used for detecting reinforcement defects, internal defects and discontinuities. Although tomography is useful in imaging defects of the same types of defects, it is very expensive, requires much experience of the researcher needed to interpret the image.

The above considerations, supplemented with author' studies presented, inter alia, in [2, 7] has led to the summary placed in Table 2 . The methods are divided into those where the suitability does not require to be experimentally confirmed and those that have to verified:

for their suitability or

whose scope of application has to be specified.

The proposed schematic procedure for the detection and identification of structural defects of saturated metallic composite castings is set forth in Figure 5. It follows from the diagram that while diagnosing castings, we first detect existing defects by any of the presented methods (Fig. 5), then we ascertain the defect type by identification. There are cases where identification, i.e. specific assignment, is done immediately after defect detection. However, for quantitative description of the structure we always have to use such tools as computer-based image analysis or statistical methods.

\section{References}

[1] Chokkalingam, B. \& Nazirudeen, S.S.M. (2009). Analysis of casting defect through defect diagnostic study approach. Journal of Engineering Annals of Faculty of Engineering Hunedoara. 2, 209-212.

[2] Gawdzińska, K. (2013). Analysis and classification of structure casts defects from metal saturated composites Unpublished doctoral dissertation, Technical University of Szczecin, Poland. (in Polish).

[3] Sobczak, J. (1996). Metal composite materials. Instytut Odlewnictwa. Kraków. (in Polish).

[4] Jaworska, L., Olszówka-Myalska, A., Cygan, S., Figiel, P., Korolyus, M. \& Cyboron, J. (2017). The influence of tungsten carbide contamination from the milling process on PCD materials oxidation. International Journal of Refractory Metals \& Hard Materials 64, 60-65. DOI.org/10.1016/ j.ijrmhm.2017.01.008.

[5] Strojny-Nędza, A. \& Pietrzak, K. (2014). Processing, microstructure and properties of different method obtained $\mathrm{Cu}-\mathrm{A} 12 \mathrm{O} 3$ composites. Archives of Metallurgy and Materials (59)4, 1301-1306. DOI.org/10.2478/amm-2014-0222.

[6] Naplocha, K. \& Granat, K. (2008). Reaction synthesis and microstructure of Al-Ti perform for composite reinforcing. Archives of Foundry Engineering. (8)1, 227-232.

[7] Gawdzińska, K., Chybowski, L. \& Przetakiewicz, W. (2015). Proper matrix-reinforcement bonding in cast metal matrix composites as a factor of their good quality. Archives of Civil and Mechanical Engineering. 16(3), 553-563. DOI: 10.1016/j.acme.2015.11.004.

[8] Timelli, G. \& Fabrizi, A. (2014). The Effects of Microstructure Heterogeneities and Casting Defects on the Mechanical Properties of High-Pressure Die-Cast AlSi9Cu3(Fe) Alloys. Metallurgical and Materials Transactions A. 45A(12), 5486-5498. DOI:10.1007/s11661014-2515-7.

[9] Ferraro, S., Fabrizi, A. \& Timelli, G. (2015). Evolution of sludge particles in secondary die-cast aluminum alloys as function of $\mathrm{Fe}, \mathrm{Mn}$ and $\mathrm{Cr}$ contents. Materials Chemistry and Physics. 153, 168-179. DOI.org/10.1016/j.matchemphys. 2014.12.050.

[10] Olszówka-Myalska, A. (2016). Some physicochemical phenomena observed during fabrication of $\mathrm{Mg}-\mathrm{C}$ cast composites. Journal of Materials Engineering and Performance. 25(8), 1-7. DOI: 10.1007/s11665-015-1877-3. 
[11] Bhedasgaonkar, R.C., Dabade, U.A. (2012). Analysis of Casting Defects by Design of Experiments Method. Proceedings of $27^{\text {th }}$ National Convention of Production Engineers and National Seminar on Advancements in Manufacturing - VISION 2020, May 2012, organized by BIT, Mesra, Ranchi, India.
[12] Kareh, K.M., Lee, P.D., Atwood, R.C., Connolley, T. \& Gourlay, C.M. (2014). Revealing the micromechanisms behind semi-solid metal deformation with time-resolved Xray tomography. Nature Communications. 5, 4464. DOI: $10.1038 /$ ncomms 5464 